\title{
A proposição cosmopolítica
}

\author{
[ The cosmopolitical proposal
}

\section{Isabelle Stengers ${ }^{\mathrm{I}}$}

Traduzido do francês: "La proposition cosmopolitique", in L'émergence des cosmopolitiques, sous la dir. de J. Lolive et O. Soubeyran, coll. Recherches, Paris, La Découverte, 2007, p. 45-68). Somos muito gratos a Isabelle Stengers pela pronta e ativa comunicação que estabelecemos ao longo deste processo de tradução. Assim, foi possível corrigir erros tipográficos ou de digitação que constam no texto original. Além disso, a autora nos enviou um importante acréscimo (ver nota Io), que contribuiu para esclarecimentos e desdobramentos do argumento, que aqui compartilhamos com o leitor. Tradução de Raquel Camargo e Stelio Marras.

STENGERS, Isabelle. A proposição cosmopolítica. Revista do Instituto de Estudos Brasileiros, Brasil, n. 69, p. 442-464, abr. 2018.

DOI: http://dx.doi.org/Io.II606/issn.23I6-90IX.voi69p442-464

I Universidade Livre de Bruxelas (ULB, Bruxelas, Bélgica). 
Como apresentar uma proposição cujo desafio não é o de dizer o que ela é, nem de dizer o que ela deve ser, mas de fazer pensar; e que não requer outra verificação senão esta: a forma como ela terá “desacelerado" os raciocínios cria a ocasião de uma sensibilidade um pouco diferente no que concerne aos problemas e situações que nos mobilizam? Como, portanto, separar essa proposição das questões de autoridade e de generalidade que se agenciam em torno da noção de "teoria"? Essa questão é ainda mais importante considerando que a proposição "cosmopolítica", da maneira como eu tentarei caracterizá-la, não se destina em primeiro lugar aos "generalistas". Ela apenas adquire sentido nas situações concretas, lá onde trabalham os praticantes; e ela requer praticantes que - e isso é um problema político, não cosmopolítico aprenderam a ser indiferentes às pretensões dos teóricos generalizantes, estes que tendem a definir aqueles como executantes, encarregados de "aplicar" uma teoria ou de capturar sua prática como ilustração de uma teoria.

Essa dificuldade é uma primeira apresentação do que será um tema deste texto: a distinção e o caráter inseparável das proposições políticas e cosmopolíticas. Tal como tentarei transmitir, é na medida mesmo em que se tornam pertinentes as proposições relevantes para o que podemos chamar de "ecologia política" - a entrada na política das questões de saberes ditos positivos ou das práticas relacionadas às "coisas" - que a proposição cosmopolítica pode também se tornar pertinente. Em outras palavras, essa proposição não tem estritamente sentido algum na maioria das situações concretas dos dias de hoje, mas ela se propõe a acompanhar aqueles e aquelas que já realizaram o "movimento político" associado à ecologia política, e que aprenderam a rir não das teorias, claro, mas da autoridade a elas associada. Um outro tema deste texto, relacionado ao primeiro, será a questão da vulnerabilidade de proposições desse gênero, expostas a todos os mal-entendidos possíveis, a começar por sua tão previsível captura teórica.

É possível que me digam, já posso prever: não precisava, afinal, retomar um termo kantiano. Com efeito, não foi Kant que renovou o antigo tema do cosmopolitismo, visando a um projeto de tipo político no âmbito de uma "Paz perpétua", na qual cada um "se pensaria como um membro integral da sociedade civil mundial em conformidade ao direito dos cidadãos”? Eu devo aqui me confessar culpada, pois ignorava o uso kantiano do termo quando, em 
I996, enquanto trabalhava no primeiro do que se tornaria uma série de sete volumes de Cosmopolitiques ${ }^{2}$, ele a mim se impôs. E quando eu descobri que o termo "cosmopolitique" afirmava a confiança kantiana em um progresso geral do gênero humano que encontraria sua expressão na autoridade de um "jus cosmopoliticum”, já era muito tarde. A palavra havia tomado para mim sua vida e necessidade próprias. Ela está, portanto, na acepção que dei a ela, marcada por uma deficiência de partida. Uma deficiência que eu aceito porque, de toda forma, ela apenas acentua a questão que se coloca a todo "nome" dado a uma proposição, no momento mesmo em que esse nome é retomado: ainda que se trate de um verdadeiro neologismo, esse nome será sempre vulnerável, e é normal que seja assim. Não é, portanto, como "proprietária" que me apresento, encarregada de transmitir a "verdadeira significação" dessa palavra, cosmopolítica, mas como protagonista interessada. Interessada na possibilidade de que entre a liberdade de retomada sem restrição dessa palavra e a obrigação de fidelidade a ela - que estaria associada a um "direito de propriedade intelectual" - se possam construir práticas que conjuguem liberdade e "rastreabilidade", colocando em cena de maneira explícita o que a retomada "faz" àquilo que foi retomado.

No presente caso, devo, portanto, afirmar que a proposição cosmopolítica, tal como eu a apresentarei, renega explicitamente todo parentesco com Kant ou com o pensamento antigo. O "cosmos", no sentido que tentarei transmitir, pouco tem a ver com o mundo no qual o cidadão antigo, por toda parte, se afirmava em seu território, nem com uma terra por fim unificada, onde cada um seria cidadão. É exatamente o contrário. Por outro lado, a "proposição cosmopolítica" poderia de fato ter afinidades com uma personagem conceitual que o filósofo Gilles Deleuze fez existir com uma força tamanha que me marcou: o idiota.

O idiota, no sentido grego, é aquele que não fala a língua grega, e que por isso está separado da comunidade civilizada. Reencontramos esse sentido na palavra "idioma", uma linguagem quase privada, que exclui, portanto, uma comunicação regida pela transparência e pelo anonimato, que é o próprio intercâmbio entre os locutores. Mas o idiota de Deleuze, que ele tomou de empréstimo de Dostoïevski para dele fazer uma personagem conceitual, é aquele que sempre desacelera os outros, aquele que resiste à maneira como a situação é apresentada, cujas urgências mobilizam o pensamento ou a ação. E resiste não porque a apresentação seja falsa, não porque as urgências sejam mentirosas, mas porque "há algo de mais importante”. Que não lhe perguntemos o quê. O idiota não responderá, ele não discutirá. O idiota faz presença, ou, como diria Whitehead', ele coloca um interstício. Não se trata de interrogá-lo: “o que é mais importante?”. "Ele não sabe." Mas sua eficácia não está em desfazer os fundamentos dos saberes, em criar uma noite onde todas os gatos são pardos. Nós sabemos, existem saberes, mas o idiota pede que não nos precipitemos, que não nos sintamos autorizados a nos pensar detentores do significado daquilo que sabemos.

2 Os sete volumes foram publicados pela Editora La Découverte, Les Empêcheurs de penser en rond, Paris, I996-I997, e republicados em dois tomos pela mesma editora (2003).

3 Ver:STENGERS, I. Penser avec Whitehead. Paris: Le Seuil, 2002. 
Eu não tenho a pretensão de me comportar à altura de um personagem conceitual. Na maior parte do tempo, como todos e cada um, eu acredito que sei aquilo que sei. Mas essa palavra, cosmopolítica, me veio em um momento no qual a inquietude me tomava, quando eu tinha a necessidade de desacelerar face à possibilidade de que, com a maior das boas vontades, eu estivesse correndo o risco de reproduzir, desde que comecei a pensar, o que aprendi ser o pecado mais recorrente da tradição à qual pertenço: transformar em chave universal neutra, isto é, válida para todos, um tipo de prática da qual nós somos particularmente orgulhosos. Eu tinha dedicado uma boa quantidade de páginas a "colocar as ciências na política", o que não significa dissolvê-las sob o modo do "isso não é senão uma política disfarçada”, mas, ao contrário, conferir ao que entendemos por política uma significação abstrata o bastante para acolher, a título de concretização particular, as práticas científicas. As ciências ditas modernas seriam uma maneira de responder à questão política por excelência: quem pode falar de que, fazer-se o porta-voz de que, representar o quêt? Mas eu corria o risco de fazer dessa questão política uma chave para a questão que eu tinha nomeado de "ecologia das práticas", invenção das maneiras que poderiam ensinar a fazer coexistir práticas diferentes, respondendo a obrigações divergentes. Eu corria o risco de esquecer que a categoria de política com a qual eu trabalhava faz parte de nossa tradição, é emprestada das fontes de invenção própria a essa tradição.

Uma tentação seria a de buscar encontrar uma categoria "verdadeiramente neutra”, antropológica, diríamos. Infelizmente, nós também somos a antropologia, assim como a ambição de definir-descobrir "o que há de humano no homem". Obstinar-se com a tentativa de formular uma proposição "anônima", igualmente válida para todos, era, de fato, cair na própria armadilha, perseguir a

4 Ver: STENGERS, I. L’invention des sciences modernes. Paris: Flammarion, I995. É inútil, porém necessário, precisar que a construção dessa posição se deu em diálogo estreito com o trabalho de Bruno Latour. 
esperança de Münchhausen de utilizar suas próprias fontes para transcendê-las5. Eu escolhi, portanto, conservar o termo "política” - que afirma que a proposição cosmopolítica é uma proposição "assinada", o que poderia eventualmente nos capacitar e se tornar "bom para pensar"-, e articulá-lo ao enigmático termo "cosmos".

É aqui que a proposição corre o risco do mal-entendido, pois o atrativo kantiano pode induzir à ideia de que se trata de uma política visando a fazer existir um "cosmos", um "bom mundo comum". Ora, trata-se justamente de desacelerar a construção desse mundo comum, de criar um espaço de hesitação a respeito daquilo que fazemos quando dizemos "bom”. Quando se trata do mundo, das questões, ameaças e problemas cujas repercussões se apresentam como planetárias, são os "nossos" saberes, os fatos produzidos pelos "nossos" equipamentos técnicos, mas igualmente os julgamentos associados a "nossas" práticas que estão na linha de frente. A boa vontade, o "respeito pelos outros" não são suficientes para apagar essa diferença, e negá-la em nome de uma "igualdade de direito" de todos os povos da terra não impedirá, posteriormente, de condenar a cegueira fanática ou o egoísmo daqueles que se negariam a admitir que não podem se esquivar das "questões planetárias". A proposição cosmopolítica é mesmo incapaz de dar uma "boa" definição dos procedimentos que permitem alcançar a "boa" definição de um "bom" mundo comum. Ela é "idiota” no sentido de que se dirige àqueles que pensam sob essa urgência, que ela não nega de forma alguma, mas vai sussurrando que, talvez, exista aí algo de mais importante.

O cosmos, aqui, deve portanto ser distinguido de todo cosmos particular, ou

5 Bruno Latour segue uma pista complementar, mas diferente, desviando-se da antropologia no seu sentido convencional, que tem o humano como categoria central, rumo à questão dos "regimes de enunciação", tal como eles se distinguem das instituições históricas e de suas pretensões autojustificativas gerais de acordo com uma relação que não é do tipo "transcendental” (condições de possibilidade), mas empírica no sentido do desdobramento aventureiro da maneira como cada regime perturba, a cada vez de maneira específica, as distribuições do bom senso moderno entre o sujeito (que age, julga, conhece, crê etc.) e seus objetos (elaborados, julgados, conhecidos, imaginados etc.). O regime de enunciação não permite julgar as instituições que correspondem a ele, não é o ideal ao qual algumas [instituições] se aproximariam mais que outras, ele propõe aproximá-las de acordo com um ângulo que coloca em cena sua irredutibilidade a todas as "razões gerais", culturais, simbólicas ou sociais. Consideradas por esse ângulo, elas devem todas aparecer de forma "surpreendente", de maneira tal que nós deixaríamos de nos surpreender com o fato de que "os outros" tenham se valido de instituições tão diferentes. Trata-se, então, de nos desenraizarmos de nós mesmos [dépayser] para que "os outros” deixem de ser exóticos aos nossos olhos. Uma tal abordagem deveria, se exitosa, descolar de maneira bastante radical o regime de enunciação política das práticas, instituições, ideais, controvérsias que nós associamos ao político, para que deixemos de nos apresentar como tendo inventado “o político", e isso sem no entanto chegar à conclusão de que outros povos "faziam política sem saber" (posição tradicional que implica que nós os compreendemos melhor do que eles compreendem a si próprios). Essa empreitada, delicada e arriscada, deve ser concebida como distinta da proposição cosmopolítica, mas as duas estão unidas por uma relação de entreprovação recíproca, visto que compartilham uma preocupação comum: sair de maneira não trivial (pós-moderna) das narrativas do progresso que conduzem até "nós" 
de todo mundo particular, tal como pode pensar uma tradição particular. E ele não designa um projeto que visaria a englobá-los todos, pois é sempre uma má ideia designar um englobante para aqueles que se recusam a ser englobados por qualquer outra coisa. $\mathrm{O}$ cosmos, tal qual ele figura nesse termo, cosmopolítico, designa o desconhecido que constitui esses mundos múltiplos, divergentes, articulações das quais eles poderiam se tornar capazes, contra a tentação de uma paz que se pretenderia final, ecumênica, no sentido de que uma transcendência teria o poder de requerer daquele que é divergente que se reconheça como uma expressão apenas particular do que constitui o ponto de convergência de todos. Não existe, enquanto tal, um representante, o idiota nada exige, não autoriza nenhum "e portanto...". E a sua questão se dirige, então, primeiramente àqueles que são os mestres do "e portanto...", a nós que, com grandes doses de "e portanto", bem poderíamos, com toda nossa boa vontade, nos tornar os representantes de problemas que, queiramos ou não, se impõem a todos.

Poderíamos dizer que o cosmos é um operador de colocação em igualdade [mise à égalité], sob a condição de dissociar radicalmente entre colocação em igualdade e colocação em equivalência [mise en équivalence], que implica uma medida comum, implicando a intercambialidade de posições. Pois dessa igualdade não se desdobra nenhum “e portanto..." mas, bem ao contrário, o põe em suspensão. Operar, aqui, é criar uma colocação em inquietude [mise en inquiétude] das vozes políticas, um sentimento de que elas não definem aquilo que discutem; que a arena política está povoada pelas sombras do que não tem, não pode ter ou não quer ter voz política: sentimento este que a boa vontade política poderia tão facilmente obliterar no momento em que uma resposta não puder ser dada à exigência "exprima-se, explicite suas objeções, suas proposições, sua relação com o mundo comum que nós construímos".

A proposição cosmopolítica, portanto, nada tem a ver com um programa, mas, muito mais com a passagem de um pavor, que faz balbuciar as seguranças. É esse pavor que podemos escutar no grito, dizem, um dia entoado por Cromwell: " $M y$ Brethren, by the bowels of Christ I beseech you, bethink that you may be mistaken!". Citar Crowell, aqui, esse tão brutal político, carrasco da Irlanda, se dirigindo aos seus irmãos puritanos, habitados por um verdade segura e vingativa, é insistir que esse balbuciamento não se merece, não traduz uma particular grandeza de alma, mas acontece. E acontece sob o modo da indeterminação, isto é, como um acontecimento ao qual nada se segue, nenhum "e portanto...", mas coloca a cada um a questão sobre a maneira como se herdará algo disso. Claro, é aos seus irmãos, enquanto cristãos, que Cromwell se dirige, e o seu endereçamento, caso exitoso, faria existir entre eles a presença do Cristo. Mas o Cristo não é, aqui, o portador de uma mensagem em particular, sua eficácia é a de uma presença sem interação, que não apela a nenhuma transação, nenhuma negociação quanto à maneira com que ela deva ser levada em conta.

Se a proposição cosmopolítica tem como ponto de atração, nas nossas experiências, o acontecimento desse pavor - “o que nós estamos fazendo?” quando fazemos um interstício no solo das boas razões que temos de fazê-lo-, ela não se resume a esse tipo de acontecimento. Os interstícios se fecham rapidamente. 
Pior, fazer calar o temor resulta frequentemente no redobramento das razões de uma vilania suplementar que estancará a hesitação. É o que nos conta, à sua maneira, a história do homem da lei que no célebre romance de Herman Melville foi confrontado com o "I would prefer not to" de seu escrivão Bartleby.

O romance de Melville é muito interessante desse ponto de vista, pois o narrador, o homem da lei que veio a tomar Bartleby como escrivão, é uma figura que retrata o que a "cosmopolítica" deve evitar. Ele insiste obstinadamente, ele quer que Bartleby saia de sua abstenção, que ele se junte ao mundo comum, onde os humanos aceitam se comprometer. Pouco a pouco ele vai se tornando quase louco, tomado pelo seu próprio jogo, e escolhe esvaziar os lugares, já que Bartleby preferiu não mais viver em lugar algum senão no seu próprio escritório. E fazendo isso ele deixa aos novos locatários a responsabilidade da qual ele não foi capaz: forçar Bartleby a fazer o que ele prefere não fazer.

A personagem de Bartleby opera uma passagem ao limite: nós nunca saberemos o sentido de uma indiferença que o leva finalmente à morte (preso por vagabundagem, ele preferirá ficar sem comer). Em contrapartida, nós podemos compreender o trajeto do homem da lei face a esse enigma. Ele combate isso, ele fica perturbado, profundamente perturbado; ele está disposto a tudo, ele não consegue não se sentir responsável, mas também não pode abrir mão das regras do jogo social que Bartleby desarticula. Ele não pode imaginar outra questão senão essa de um retorno de Bartleby a um mundo comum. Quando os clientes se chocam com a recusa desse escrivão desocupado, que prefere não prestar-lhes os serviços que pedem, ele não considera compartilhar com eles sua "idiotice", e é sem dúvida isso que o condena à vilania: mudar-se do seu escritório a fim de poder lavar as mãos do destino desse irresponsável, sabendo que outros resolverão a questão em seu lugar.

É preciso ser cauteloso quanto à boa vontade individual. Conferir uma dimensão "cosmopolítica" aos problemas que pensamos sob o modo da política não se refere ao registro das respostas, mas coloca a questão sobre a maneira como podem ser escutados "coletivamente", no âmbito do agenciamento através do qual se propõe uma questão política, o grito de pavor ou o sussurro do idiota. Nem o idiota, nem Cromwell apavorado, nem o homem da lei obcecado por Bartleby o sabem. Não se trata de se dirigir a eles, mas de agenciar o conjunto de maneira tal que o pensamento coletivo se construa "em presença" da questão insistente que eles fazem existir. Dar a essa insistência um nome, cosmos, inventar a maneira mediante a qual a "política", que é a nossa assinatura, poderia fazer existir seu "duplo cósmico" [doublure cosmique], as repercussões disso que vai ser decidido, disso que constrói suas razões legítimas, sobre isso que permanece surdo a essa legitimidade, eis a proposição cosmopolítica.

Eu gostaria de citar aqui um exemplo concreto do que pode significar esse "em presença”. O exemplo concerne à questão, doravante colocada na política, da experimentação animal. Deixemos de lado os casos múltiplos nos quais podemos dizer que "há abuso", crueldade inútil e cega ou redução sistemática dos animais de criação ao status de carne sobre patas. O que me interessa são os casos difíceis, nos quais são "colocadas na balança” a experimentação e uma causa que consideramos 
legítima, a luta contra uma epidemia, por exemplo. Alguns tentaram criar escalas de valor que permitem "medir" o interesse humano e estabelecer a possibilidade de colocar em relação esse interesse e uma medida dos sofrimentos infligidos a determinado tipo de animal (o sofrimento de um chipanzé "conta" mais do que o de um rato). Mas essa colocação em equivalência de tipo utilitarista abre a todo tipo de vilania: ela incita cada um a reenviar à conta comum a responsabilidade das consequências de sua própria medida. Outros, e isso foi o que me interessou, designaram um ponto de atração inesperado. Nós sabemos que nos laboratórios onde se pratica a experimentação animal existe todo tipo de rito, de maneira de falar, de designar os animais, o que testemunha a necessidade dos pesquisadores de se protegerem. Poderíamos, ademais, nos perguntar se as grandes evocações do progresso dos conhecimentos, da racionalidade, das necessidades do método, não fazem parte desses ritos, obstruindo os interstícios por onde insiste o "o que estou fazendo"6. A necessidade de "decidir" quanto à legitimidade de uma experimentação teria então por correlato a invenção de restrições destinadas ativamente a essas manobras de proteção, forçando os pesquisadores implicados a se expor, a decidir "em presença" daquilo que será eventualmente vítima de sua decisão. A proposição vai então no sentido de uma “autorregulação", mas ela tem por interesse colocar em cena a questão do "auto", de dar a sua plena significação ao desconhecido da questão: o que decidiria o pesquisador "por ele mesmo" se esse "ele mesmo" estivesse ativamente despojado daquilo que as decisões atuais parecem ter necessidade.

Uma tal questão destaca uma perspectiva que chamo de "eto-ecológica" [étho-écologique], que afirma a inseparabilidade do éthos, da maneira de se comportar própria a um ser, e do oikos, do hábitat desse ser, da maneira que esse hábitat satisfaz ou contraria as exigências associadas a tal éthos, ou oferece aos novos éthos a oportunidade de se atualizarem7. Quem diz inseparabilidade não diz dependência funcional. Um éthos não é uma função do seu meio ambiente, do seu oikos, ele sempre será o éthos do ser que se revela capaz dele. Nós não o transformaremos de modo previsível transformando o meio ambiente. Mas nenhum éthos é, em si mesmo, detentor da sua própria significação, mestre de suas razões. Nós não sabemos de que um ser é capaz, do que pode se tornar capaz. O meio ambiente, poderíamos dizer, propõe, mas é o ser que dispõe dessa proposição, que lhe dá ou lhe nega uma significação “etológica”. Nós não sabemos do que um pesquisador, afirmando hoje a legitimidade, mesmo a necessidade de

6 Em De l'angoisse à la méthode dans les sciences du comportement (Paris: Flammarion, I980), Georges Devereux liga a importância do método nas "ciências do comportamento", isto é, as ciências que se dirigem a seres que, eles próprios, se dirigem ao mundo, à necessidade de se proteger de uma angústia que o físico ou o químico não conhecem (“o que eu estou fazendo a 'ele'?"). É por isso que o método, nessas ciências, acaba sempre, de uma maneira ou de outra, por rebaixar de forma insensata o observado (p. 80), mas também a "emburrecer" o pesquisador, que se apresentará como submisso ao método, tirando mérito das economias de pensamento e da sensibilidade que ele exige.

7 Sobre esse tema, ver o bonito livro de DESPRET, V. Quand le loup habitera avecl'agneau. Paris: Les Empêcheurs de penser en rond, 2002. 
determinada experimentação animal, poderia se tornar capaz em um oikos que lhe exige pensar "em presença" das vítimas de sua decisão. O que importa é que esse devir será aquele de um pesquisador, e é nesse devir que ele produziria um acontecimento e no qual aquilo que chamo de "cosmos" poderia ser nomeado. Localmente, no caso em que a exigência ecológica seria eficaz, uma articulação terá sido criada entre o que parecia se contradizer: as necessidades da pesquisa e suas consequências para os animais que são vítimas dela. Acontecimento "cósmico".

Esse exemplo pode fazer sentir o motivo pelo qual eu enfatizei que o idiota não nega os saberes articulados, não os denuncia como mentira nem como a fonte escondida de um conhecimento que os transcende. Os constrangimentos [contraintes] propostos são "idiotas" nesse sentido: eles não designam um árbitro capaz de julgar a legitimidade das urgências que os experimentadores reivindicam, eles levam a sério, a título hipotético (isso pode não funcionar) o fato de que o éthos desses experimentadores, que é definido como problemático pelos adversários da experimentação animal, parece ter necessidade de um ambiente "asséptico", e eles lhes negam o direito a tal ambiente: nós poderemos aceitar escutar os seus argumentos quando estivermos seguros de que vocês estão plenamente expostos às suas consequências.

Portanto, o problema não é o dos saberes articulados, mas da pretensão que redobra esses saberes: aqueles que sabem se apresentam como pretendendo saber aquilo que sabem, como sendo capazes de conhecer de um modo independente de sua situação "ecológica", independente do que o seu oikos lhes obriga a levar em conta, ou, ao contrário, lhes permite ignorar. O que o idiota sussurra não transcende os saberes e não possui em si mesmo qualquer significação. É o modo como esse sussurro modificará eventualmente (na forma de um acontecimento) não as razões, mas a maneira como as razões daqueles que discutem se apresentam, que pode resultar nessa significação.

Seria muito interessante, mas eu me limitarei aqui a uma simples alusão, prolongar esse exemplo a outros casos nos quais a anestesia parece parte interessada de uma situação. Assim, nós estamos inundados de discursos que nos pedem para aceitar que os fechamentos de usinas e o desemprego de milhares de trabalhadores são uma consequência dura, porém inevitável da guerra econômica. Se nossas indústrias não podem fazer "os sacrifícios" que a competitividade exige, elas serão vencidas, e nós seremos todos perdedores. Que seja, mas é preciso então nomear e honrar os desempregados como vítimas de guerra, aqueles cujo sacrifício nos permite sobreviver: cerimônias, medalhas, desfiles anuais, placas comemorativas, todas as manifestações do reconhecimento nacional, em suma, todas as manifestações de uma dívida que nenhuma vantagem financeira será suficiente para compensar lhes são devidas. Mas imagine-se as repercussões se todos os sofrimentos e mutilações impostos pela guerra (econômica) fossem assim "celebrados", rememorados, ativamente protegidos do esquecimento e da indiferença, e não anestesiados pelos temas da flexibilidade necessária, da ardente mobilização de todos por uma "sociedade de conhecimentos” onde cada um deverá aceitar a rápida obsolescência do que sabe 
e tomar para si a responsabilidade permanente de sua autorreciclagem. $O$ fato de sermos tomados por uma guerra sem perspectiva concebível de paz se tornaria talvez intolerável. Proposição “idiota”, pois não se trata de um programa para um outro mundo, de um afrontamento entre razões, mas de um diagnóstico quanto ao modo de estabilidade "eto-ecológica" deste mundo daqui.

Eu gostaria agora de desdobrar a proposição cosmopolítica em associação com o tema da ecologia política, tal como permitem entrever os trabalhos de Bruno Latour (Politiques de la nature) ou de Michel Callon e seus coautores (Agir dans un monde incertain). Não se trata nem de criticar, nem de afirmar o preenchimento de uma "falta", mas de insistir explicitamente. A cultura ativa da incerteza, tal como a propõem notadamente Callon e seu coautores, já é um desafio formidável, e contudo, de maneira idiota, trata-se de complicar ainda mais a situação; de marcar o fato de que vivemos em um mundo perigoso e de levar em conta explicitamente esse perigos.

Eu preciso antes de mais nada enfatizar o desafio formidável que constitui em si mesmo a ecologia política, a ideia, para falar rapidamente, de uma produção pública, coletiva, de saberes em torno de situações que nenhuma expertise particular pode ser suficiente para definir, e que requerem a presença legítima ativa, objetora e propositiva, de todos que estão "implicados". Como diz Bruno Latour, trata-se de fazer com que a situação escape das razões autorizadas pelos matters of fact, como também dos valores dedutíveis de um "interesse geral" que permite a arbitragem. A situação deve ser produzida como matter of concern, o que significa que ela deve agrupar em tornar de si aqueles que estão "implicados". Ora, sabemos, há tantos meios de fabricar uma situação aparentemente aberta, na qual todos os poderes de objetar e de propor são acolhidos, mas o são em condições tais em que, de fato, os dados estão viciados, as forças são desiguais. Por exemplo, as modificações que afetarão uma proposição sustentada por uma expertise que se beneficia de meios desmedidos em relação aos outros podem apenas ser cosméticas. Esse desafio é político, e nós podemos apenas entrever o alcance e amplitude das suas consequências. É na França, em particular, que todo o papel do Estado está notadamente em questão, com uma transformação da cultura política de seus funcionários.

O que demandaria a passagem de funcionários encarregados de assegurar que as proposições já munidas de uma legitimidade de fato, de uma aliança já formulada com o interesse geral, sejam submetidas ao "debate público", a funcionários cuja grandeza seria a de manter uma posição de um "não saber radical” em relação ao que é do "interesse geral”, e cuja tarefa seria assegurar que toda proposição se apresente de um modo que a exponha efetivamente, o mais efetivamente possível, e que todos os objetores-proponentes tenham os meios de desdobrar plenamente a sua proposição? É toda a política de pesquisa pública que deveria, notadamente, ser revista.

É nessa medida que a ecologia política constitui já uma aposta eco-etológica. Com efeito, a ideia, propriamente política, da possibilidade de uma transformação do papel do Estado tem por interesse primeiro o de propor uma forma de considerar os fracassos e as contrafações do debate público, bem como a 
maneira pela qual as "boas intenções" dão lugar a consequências perversas, de um modo que se distancia de toda conclusão geral, reenviando a generalidades incontornáveis (a ciência, a expertise, o interesse geral, os constrangimentos administrativos) a responsabilidade pelo fracasso, pela contrafação ou perversão. Trata-se de suscitar um "ambiente" recalcitrante a tais generalizações fatalistas: não há lugar para estar "decepcionado”, como se vivêssemos em um mundo onde as boas intenções proclamadas pudessem ser tidas por confiáveis, mas há lugar para aprender a descrever com precisão a maneira como as histórias que nós podíamos ter pensando como sendo promissoras acabam por se voltar ao fracasso, à contrafação ou à perversão: em outras palavras, construir uma experiência e uma memória ativas, compartilháveis, criadoras de exigências políticas. Para isso, é preciso, evidentemente, que os pesquisadores interessados assumam o risco de construir seus saberes de um modo que os torne "politicamente ativos", engajados na experimentação do que pode fazer a diferença entre sucesso e fracasso ou contrafação. Não se constituirá jamais memória ou experiência sob o signo de uma neutralidade metodológica. Isso não significa "abandonar a ciência”. Jamais teria existido ciência experimental se os pesquisadores no laboratório não estivessem apaixonadamente interessados pela diferença entre aquilo que "funciona", que cria uma relação pertinente, que produz um saber que importa, que pode interessar, e uma observação metodologicamente impecável, mas que não é suscetível de criar qualquer diferença, qualquer consequência.

Mas a aposta eto-ecológica associada à ecologia política supõe igualmente que as práticas produtoras de saber não possuem elas próprias a necessidade de um árbitro externo, que detém a responsabilidade de fazer com que o interesse geral prevaleça. Caso contrário, a questão da diferença entre o sucesso e o fracasso ou a contrafação seria vazia, e a questão política não se colocaria. Essa aposta supõe então a possibilidade de um processo no qual a situação problemática em torno da qual se reúnem os "experts" - aqueles que possuem os meios de objetar e de propor - tenha o poder de obrigá-los. É por isso que, desde o começo, adiantei que nada disso do que eu sugiro possui o mínimo sentido se aqueles a quem me dirijo não tiverem aprendido a dar de ombros diante do poder de teorias que os define como executantes. Pois o poder das teorias é o de definir cada situação como um simples caso, isto é, proibir aos seus representantes de serem obrigados a pensar, de serem colocados em risco por esse caso. A aposta eto-ecológica implica, portanto, que o "éthos" associado ao pesquisador incapaz de abandonar a posição de porta-voz de uma teoria (ou de um método) que supostamente faz dele um cientista, não é nem um pouco um problema grave e inultrapassável (do tipo: é isso ou recairemos ao nível da opinião). Trata-se de uma questão do meio. Esse éthos, no meio atual, permite fazer carreira, mas, se o meio muda de um modo que o transforma em uma deficiência risível, ele pode ser modificado.

A ecologia política se situa, pois, na perspectiva do que poderíamos chamar de uma "utopia", mas existem inúmeros tipos de utopia. Algumas permitem fazer a economia do mundo em nome de uma promessa que o transcende. Outras, e é o caso aqui, penso eu, incitam a se dirigir a este mundo com outras questões, a resistir às palavras de ordem que o apresentam como "aproximadamente 
normal”. A utopia não autoriza, portanto, a denunciar este mundo em nome de um ideal, mas ela propõe uma leitura dele indicando por onde poderia passar uma transformação que não deixe ninguém intacto, isto é, que coloque em questão todos os "teríamos apenas que..." que designam a simplista vitória dos bons contra os maus. E a proposição cosmopolítica reitera esse tipo de utopia, carregada pela memória de que vivemos em um mundo perigoso, onde nada é óbvio.

Uma lembrança: aqui, em Cerisy, Michel Callon veio falar dos "fóruns híbridos", essa figura emblemática da transformação de um situação em "matter of concern" coletivo. Tudo que ele disse era muito justo, muito pertinente, muito bem pensado, mas isso não impediu a discussão. Cada um sabia, reconhecia e já praticava. Um museu poderia ser apresentado como um fórum híbrido, uma conferência interdisciplinar também, e mesmo as comissões encarregadas do plano quinquenal. E um economista falou de maneira triunfal: "mas nós conhecemos bem isso, o fórum híbrido por excelência é o mercado!”. Com efeito, não é o mercado que reúne todos aqueles que estão implicados, todos que possuem um interesse em uma situação, todos aqueles cujos interesses contraditórios dão seu relevo à situação e fazem finalmente, sem arbitragem exterior, emergir a solução que articulará a todos?

Eu já tinha tido essa impressão de horror quase surrealista quando descobri o modo como um tema que eu tomava por associado às práticas dos ativistas americanos - em particular daqueles que buscam se tornar capazes de ações não violentas -, o empowerment, tinha sido, doravante, retomado um pouco por toda parte. Tratava-se, desde então, de "restituir" aos stakeholders, àqueles que possuem interesse em uma situação, a responsabilidade de decidir eles próprios, livres dos pesos limitadores de regras que os impedem de determinar o que é melhor para eles. É inútil precisar que as regras aqui em questão, das quais se trata de se libertar, são o que resta de criações políticas destinadas a limitar as relações de força, a impedir que as desigualdades se aprofundem, a criar uma relativa solidariedade contra a plena exploração das vantagens de uma situação. "Nós temos o direito de nos beneficiarmos de nossa situação, nós reivindicamos que nos restituam a possibilidade de tirar plena vantagem dela", eis o que se tornou o empowerment, e o mesmo destino espera, sem dúvida, qualquer outra possibilidade de pôr em causa a relação entre Estado e arbitragem em nome do interesse geral. Da mesma forma que uma empresa privada é fatalmente mais bem gerida do que um empresa pública, uma "boa governança” emergirá fatalmente do fato de que o Estado renuncia à pretensão inoportuna de se ingerir nos negócios dos stakeholders.

Nós vivemos em um mundo perigoso, e aqui podemos pensar na antiga análise de Joseph Needham ${ }^{8}$ na qual ele se pergunta por que, na Europa, invenções técnicas que a China tinha absorvido podiam ser colocadas na origem do que chamamos de "revolução industrial". Muitos diziam, e eu ainda escutei dizer recentemente: foi a física que fez a diferença, a grande descoberta da fecundidade

8 NEEDHAM J. La science chinoise et l’Occident. Paris: Le Seuil, I973. 
das matemáticas para descrever o mundo. Needham não parou aí: como embriologista, ele sabia a que ponto essa fecundidade era limitada. Os trabalhos de Galileu ou Newton nada explicavam, mas o fato de que eles tenham podido "fazer evento" é que devia ser explicado. E a explicação que ele reteve foi a que coloca em cena a liberdade que então beneficiava os "empreendedores" europeus - aqueles que Latour mais tarde descreveu como ativando a construção de redes cada vez mais longas, a despeito de toda estabilidade ontológica, enlaçando sem hesitação os interesses humanos aos não humanos, cada vez mais numerosos e heteróclitos. Galileu é, de fato, um construtor de redes: seu conhecimento, no fim das contas, concernia primeiramente à forma como algumas esferas bastante lisas rolam ao longo de um plano inclinado, e esse conhecimento, somado às suas observações com a luneta, lhe permitiu acrescentar argumentos em apoio a uma hipótese astronômica; mas ele colocou tudo isso em comunicação direta com a grande questão da autoridade, dos direitos do conhecimento que se iniciam diante das tradições filosóficas e teológicas. E a sua condenação nada impediu na Europa esfacelada entre estados rivais, enquanto que, Império unificado que era a China, ele teria sido sem dúvida proibido de empreender.

Os stakeholders, aqueles que possuem interesses em um novo empreendimento e que por ele se conectam, não devem ser limitados pelo que quer que seja exterior aos seus empreendimentos: o mundo emerge da multiplicidade de suas conexões heterogêneas, e essa emergência tem por única "mecânica" os entreimpedimentos que eles constituem uns para os outros. Nós sempre ressaltamos a ligação entre essa concepção da livre emergência, sem transcendência, com a mecânica. Os empreendedores (e um consumidor é igualmente um empreendedor) "compõem" à maneira de forças mecânicas, por adição; e a emergência não é outra coisa que a consequência dos obstáculos fatuais que eles constituem uns para os outros. Cada empreendedor é, então, movido por seus interesses bem definidos. Certamente, ele pode estar aberto a tudo aquilo que lhe permite avançar (ver os mecanismos de recrutamento descritos por Bruno Latour em La science en action). Mas o essencial é que ele seja o homem da "oportunidade", surdo e cego à questão do mundo de cuja construção os seus esforços participam. Com efeito, é precisamente essa desconexão das escalas - aquelas dos indivíduos e aquela do que, juntos, eles fazem emergir - que permite a matematização do "mercado" como composição automática, maximizando uma função que os economistas escolherão assimilar ao bem coletivo. Toda intrusão em nome de um outro princípio de composição, mas também toda "escuta/acordo [entente]", isto é, toda distância em relação à surdez, podem então ser colocados no mesmo saco: eles não serão descritos, mas condenados, pois todos têm o efeito de diminuir aquilo que o "livre mercado" maximiza (poder do teorema matemático).

É isso que o Greenpeace bem compreendeu quando opôs aos stakeholders aquilo que ele nomeou como shareholders, palavra um pouco infeliz, pois ter "fatias de mercado" é ter um interesse bem definido, mas que vale pelo seu contraste: trata-se de dar voz àqueles que pretendem "tomar parte", "participar", mas em nome daquilo que emerge, em nome das consequências, das repercussões, de tudo aquilo cujos diferentes interesses fazem a economia. Em poucas palavras, 
trata-se de opor aos empreendedores - definidos pelos seus interesses, por aquilo que os concerne - aqueles que "se envolvem com aquilo que não deveria concernir a ninguém”, aquilo que não deveria intervir na composição de forças.

A questão, certamente, é política, e o direito de empreender permanece hoje, desse ponto de vista, como a primeira palavra. O princípio de precaução tende a limitar um pouco esse direito, mas ele o respeita antes de mais nada: para limitá-lo, é preciso estar em jogo a saúde humana ou os danos graves e/ ou irreversíveis ao meio ambiente. Não há, então, lugar para a questão dos shareholders: em que mundo queremos viver?, mas apenas desenvolvimento da possibilidade de uma posição defensiva. Certamente, a ideia de "sustentabilidade" vai mais longe, mas não nos surpreendamos que se trate apenas de uma ideia: a sua aplicação efetiva transformaria o “direito" de empreender em "proposição", e implicaria que as ideias da ecologia política se tornassem realidade institucional.

No nosso mundo perigoso, o primeiro sentido da proposição cosmopolítica é o de "completar", isto é, de complicar explicitamente a ideia de ecologia política de maneira tal que ela se torne (talvez) inassimilável pelos stakeholders, de maneira tal que eles não possuam mais os meios de "reconhecê-la", nem de enquadrá-la na sua oposição - seja a livre composição de interesses, seja a intrusão indesejada de uma transcendência, Estado, plano, em nome de um conhecimento que não pertence a ninguém (o mercado "sabe mais").

Eu destaquei o caráter mecânico da emergência por composição dos interesses. Eu seguirei essa pista a fim de verificar se as ciências da natureza nos fornecem outros modelos de emergência sem transcendência. Certamente, o primeiro que se apresenta é o modelo biológico: a vida democrática poderia ser assimilada à harmoniosa participação de cada um em um corpo único... Velha ideia, muito sedutora, à qual convém, entretanto, resistir. Pois esse corpo, a serviço do qual cada um encontraria sua verdade e sua realização, é uma péssima mistura, antipolítica, de naturalismo e de religião.

Não é nem um pouco certo que um corpo vivo funcione como esse modelo harmônico - leiam sobre esse tema Ni Dieu ni gène, de Kupiek e Sonigo', que realizaram a "libertação" da biologia do ideal de uma coincidência imediata, para cada parte, entre "se realizar" e "contribuir para o bem comum". Mas o corpo, qualquer que seja a descrição que a biologia der dele, não é um modelo político, pois o que se deve compreender a esse respeito, aquilo de que depende a sua sobrevivência, é uma relativa estratificação, o que podemos chamar de uma dissociação de escalas (células, órgãos, organismos). Quando o corpo está doente, torna-se muito mais difícil descrevê-lo, pois a estratificação que permitia a estabilidade das referências descritivas desaparece. De uma maneira ou de outra, as "escalas" existentes nas sociedades humanas são correlatas: o indivíduo pensa a sua sociedade. Cada vez que a referência biológica prevalece, o pensamento se torna o inimigo, pois ele confunde as escalas.

O ideal de uma composição harmônica poderia ser caracterizado como o "outro" do espírito de empresa, um sonho (não é assim que as sociedades

9 KUPIEK J.-J;; SONIGO P. Ni Dieu ni gène. Paris: Le Seuil, 2003. (coll. Points science). 
tradicionais funcionam) que se torna um pesadelo no momento em que ele busca a sua própria realização, pois ele se limita a inverter os polos do modelo mecânico em relação a uma invariante. O que não varia é que a composição não tem necessidade de pensamento político, de dúvida, de imaginação quanto às consequências. O corpo "sabe mais", ele é o cosmos, um cosmos realizado, não aquilo que insiste no sussurro do idiota, daquele que duvida. E, de maneira previsível, a intuição, o instinto, o sentir imediato serão celebrados contra os artifícios do pensamento.

Se o "cosmos" pode nos proteger de uma versão "empreendedorista" da política, acolhendo apenas os interesses bem definidos, que têm os meios para se entreimpedir, nós vemos no momento que a política pode nos proteger de um cosmos misantropo, de um cosmos que se comunica diretamente com uma verdadeira oposição aos artifícios, hesitações, divergências, desmedidas, conflitos associados às desordens humanas. O modelo de harmonia biológica é bastante esmagador. Pensar o que emerge é resistir tanto à composição mecânica de forças indiferentes quanto à composição harmônica do que apenas encontra a sua verdade no fazer corpo.

Mas existe ainda um outro modelo de emergência, que não remete nem à física, ciência das leis que confirmou a palavra de ordem "obedecer à natureza para poder submetê-la”, nem à biologia, ciência dos modos de manter junto, da qual depende a vida ou a morte do corpo. Trata-se da arte dos químicos que compreendem isso com que estão lidando a partir do que existe para lhes permitir fazer.

Falar da arte do químico é se voltar não para a química contemporânea, que frequentemente se pensa como uma espécie de "física aplicada", mas para aquela química do século XVIII, que alguns pensadores das Luzes (notadamente Diderot, e certamente não Kant, que é muito mais o abajur dessa aventura das Luzes) opuseram ao modelo mecânico, ao ideal de uma definição teórica dos corpos químicos da qual se deveria deduzir o modo como eles entram em reação (esse "ideal" está longe de ser alcançado pela química contemporânea). Se existe arte, é porque os corpos químicos são definidos como "ativos”, mas sua atividade não pode ser atribuída a eles, ela depende das circunstâncias e pertence à arte dos químicos criar tipos de circunstâncias nos quais os corpos se tornarão capazes de produzir o que o químico deseja: arte de catálise, de ativação, de moderação.

Se vocês lerem o bonito livro de François Jullien, La propension des choses, descobrirão uma arte de emergência bastante próxima daquela do químico. Com efeito, nesse livro se encontra descrito o modo como os chineses honram aquilo que menosprezamos, a manipulação, a arte da disposição que permite aproveitar-se da propensão das coisas, de “dobrá-las" de tal sorte que elas realizem "espontaneamente" o que o artista, o homem de guerra ou o homem político desejam. Fora da oposição entre submissão e liberdade, um pensamento centrado na eficácia.

Dir-se-á que esse é um estranho modelo para o político, mas esse sentimento de estranheza traduz nossa ideia de que a "boa" política deveria encarnar uma forma de emancipação universal: removam a alienação que separava os humanos da sua liberdade e vocês obterão qualquer coisa parecida com uma democracia. A ideia de uma arte, mesmo de uma “técnica” política, é, portanto, anátema, artifício que separa 
o humano da sua verdade. Referir-se à arte do químico é afirmar que o encontro político não tem nada de espontâneo. O que chamamos de democracia ou é a forma menos ruim de gerir o rebanho humano ou é uma aposta centrada na questão não do que são os humanos, mas do que eles podem se tornar capazes. É a questão que John Dewey colocou no centro da sua vida: como "favorecer", "cultivar" os hábitos democráticos? E essa questão, considerando que a referência à química propõe colocá-la de maneira técnica, pode ser prolongada pela questão "cosmopolítica": como, por quais artifícios, por quais procedimentos, desacelerar a ecologia política, conferir uma eficácia ao sussurro do idiota, esse "há algo de mais importante" que é tão facilmente ignorado, já que ele não pode ser “levado em conta”, pois o idiota nem objeta nem propõe nada que "conta”. A questão é "eto-ecológica”: qual oikos pode dar lugar à emergência do que seria capaz de "importar", o que não pode ser imposto?

Não é uma questão de boa vontade, individual ou coletiva, pois o que se trata de pensar é da ordem do acontecimento. Mas o acontecimento não remete, certamente, à inspiração inefável, à revelação súbita. Ele não se opõe à explicação. É o alcance da explicação que se encontra transformado, articulado ao registro da arte e não da dedução. Não se explica um acontecimento [événement], mas o acontecimento se explica a partir daquilo que terá sabido nele criar um lugar ${ }^{\mathrm{T}}$. E uma tal arte me parece operar nos dispositivos que são facilmente desqualificados como supersticiosos, porque eles parecem convocar uma transcendência.

Eu penso principalmente naquilo que pude aprender com o dispositivo do "discurso" e com a maneira com que ele faz intervir o que eu chamaria, em poucas palavras, a ordem do mundo. O que há de muito interessante é que esse dispositivo

Io Diante da emergência de um sentido um pouco enigmático quando da tradução dessa frase para o português, pedimos à autora que nos ajudasse a esclarecê-la. Sua resposta, cuja tradução e publicação nos foram autorizadas a nosso pedido, acrescenta esclarecimentos, tal como segue: “O acontecimento se explica: é preciso entender que é o acontecimento ele mesmo que produz a maneira como ele será caracterizado - e a partir daquilo que o situa. O que significa: um acontecimento não possui "em si mesmo" o poder de fazer acontecimento, mas ele também não é apenas relativo à situação no sentido geral, como se pudéssemos deduzi-lo dessa situação (explicação sociológica). A situação não explica o acontecimento, ela poderia ter acolhido outros [em seu lugar]. Mas ela permite compreender a criação do lugar que é aquele deste acontecimento, isto é, compreender a maneira como este acontecimento se situará. O acontecimento se situa ativamente em relação à situação, ele intervém na situação. Ele se ampara em certos elementos da situação e cria um lugar, ou um ponto de vista, que permite caracterizá-la. Por exemplo, na época de Galileu, a situação é aquela de uma crise da autoridade, mas o acontecimento Galileu, isto é, a criação de um lugar onde essa questão da autoridade é ao mesmo tempo dramatizada (todas as nossas interpretações são ficções?) e encontra uma solução pela intervenção do fato experimental - que faz autoridade. Galileu 'faz acontecimento' propondo os fatos como solução geral à crise. Ele cria o 'laboratório' como lugar do acontecimento 'nascimento da ciência como capaz por de acordo os humanos'. O acontecimento se explica a partir do tipo de fato obtido no laboratório no sentido novo do termo, no sentido em que o laboratório é o lugar onde se inventam dispositivos experimentais que dão 'o poder de conferir às coisas o poder de conferir ao experimentador o poder de falar em seu nome' (Invention des sciences modernes, p.IO2). Na China, onde a situação não era aquela de uma crise de autoridade, a ciência que os missionários apresentaram fez sorrir os letrados, mas os chineses muito apreciaram os relógios...”. (N.T.) 
ritual, que parece supor a existência de uma ordem do mundo que dará a sua justa solução a uma situação problemática, não confere qualquer autoridade a essa ordem. Se existe um discurso [palabre], é porque aqueles que se reúnem, aqueles que são reconhecidos como sabendo de alguma coisa dessa ordem não sabem, nesse caso específico, como ela vai se passar. Se eles estão reunidos, é por conta de uma situação em relação à qual nenhum de seus saberes é suficiente. Portanto, a ordem do mundo não é um argumento, ela é aquilo que confere aos participantes um papel que os “des-psicologiza”, que faz com que eles não se apresentem como "proprietários" das suas opiniões, mas como aqueles que se encontram todos igualmente habilitados a testemunhar que o mundo possui uma ordem. É por isso que ninguém discute o que diz o outro, não contesta, não questiona a pessoa.

Do ponto de vista dos saberes dos antigos químicos, o fato de que o discurso [palabre] não pede aos protagonistas que decidam, mas que determinem como se passa aqui a ordem do mundo, confere a essa ordem um papel que seria aquele do ácido que desagrega os corpos e lhes permite entrar em proximidade, e também do fogo que os ativa. Em poucas palavras, pode-se caracterizar a ordem do mundo em termos de eficácia: ela constrange cada um a se produzir, a fabricar-se a si mesmo, a partir de um modo que confere ao problema em torno do qual eles se reúnem o poder de gerar pensamento, um pensamento que não pertencerá a ninguém e a ninguém dará razão.

Segundo exemplo e segunda lembrança - parece que ainda falamos sobre isso nas casas de campo parisienses. Aqui, em Cerisy, uma bruxa foi convidada! Starhawk, que é, além do mais, uma californiana: nem é uma autêntica velha proveniente das profundezas da antiga Berry, mas uma dessas americanas que acreditam ser tudo permitido, que pensam que podemos escolher virar as costas à modernidade como nosso destino. Uma ativista que se apresenta a si e aos seus como produtores de rituais, experimentando o que elas e eles ousam chamar de "magia", definida não em termos de poderes sobrenaturais, mas em termos de eficácia.

Nós continuamos a falar de magia nos diversos registros. Nós falaremos da magia negra dos grandes rituais nazistas, mas também da magia de um momento, de um livro, de um olhar, de tudo que torna capaz de pensar e sentir de outra maneira. O termo magia, entretanto, não é pensado, e o mesmo acontece com todas palavras associadas à sua eficácia. Para as bruxas, nomear-se bruxas e definir a sua arte por essa palavra, "magia”, já são atos “mágicos”, que criam uma experiência desconfortável para todos aqueles que vivem em um mundo onde supostamente a página foi definitivamente virada, com a erradicação de tudo que foi desqualificado, menosprezado, destruído, enquanto triunfava o ideal de uma racionalidade pública, de um homem idealmente mestre de suas razões, logo acompanhado da trivialidade da psicologia dita científica com suas pretensões de identificar aquilo a que as razões humanas obedecem. Ousar nomear de "magia" a arte de suscitar os acontecimentos nos quais está em jogo um “tornar-se capaz” é aceitar que se deixe ecoar em nós um grito que pode lembrar aquele de Cromwell: o que fizemos, o que continuamos fazendo quando utilizamos palavras que nos fazem os herdeiros daqueles que erradicaram as bruxas.

A magia que as bruxas ativistas americanas cultivaram no domínio político é 
uma arte experimental cuja pedra de toque é um êxito indeterminado quanto ao seu conteúdo. Com efeito, essa arte mantém algo daquilo que poderíamos chamar de convocação: o ritual aí chama a uma presença, mas aquilo que é convocado - o que as bruxas chamam de deusa - não diz (não mais que o Cristo de Cromwell) o que é preciso fazer, não dá resposta à decisão que tomar, não entrega qualquer visão "profética”. A sua eficácia é bem antes aquela de catalisar um regime de pensamento e de sentir que confere àquilo que importa, àquilo em torno do que se dá a reunião, o poder de se tornar causa de pensamento. A eficácia do ritual não é, portanto, a convocação de uma deusa que inspiraria a resposta, mas a convocação daquilo cuja presença transforma as relações que cada protagonista entretém com os seus próprios saberes, esperanças, medos, memórias, e permite ao conjunto fazer emergir o que cada um, separadamente, não teria sido capaz de produzir. Empowerment, produção graças ao coletivo, de partes capazes daquilo que elas não teriam sido capazes sem ele. Arte de imanência radical, mas a imanência é precisamente aquilo que está para se criar, sendo o regime usual de pensamento aquele da transcendência que autoriza posição e julgamento.

Evidentemente, nem os discursos [palabres], nem os rituais de bruxas são modelos, mas apenas casos cuja importância é a de nos livrar dos "ou bem isso... ou bem aquilo...” que desmembram nossas imaginações. Eu penso principalmente na grande alternativa dos "cidadãos nus", cada um armado apenas de sua boa vontade supostamente desinteressada, e todos confrontados à questão do interesse geral, ou triunfo dos interesses corporativos indiferentes a esse interesse geral. Essa alternativa aparece como inultrapassável à medida que prevalece a generalidade, à medida que o interesse geral é o único que pode se impor de maneira legítima aos interesses (egoístas). Ela aparece, por outro lado, completamente inadequada na perspectiva da ecologia política, pois aquilo que reúne é tudo, menos uma generalidade (quais são nossos "valores"?), mas um problema que não apenas não se deixa dissociar em termos de fatos-valores, mas que tem a necessidade de pôr em presença ativa aqueles que possuem um saber pertinente acerca do que está em questão.

A ecologia política afirma que não existe conhecimento que seja ao mesmo tempo pertinente e separado: não é de uma “definição objetiva”, de um vírus ou de uma inundação que podemos ter necessidade, mas daqueles cujas práticas foram engajadas de modos múltiplos “com” esse vírus ou "com” esse rio. Mas cabe à perspectiva cosmopolítica colocar a questão da eficácia, que poderia estar associada ao "não existe" da ecologia política, e de conceber a cena política a partir dessa questão. Como o processo de emergência da decisão política pode, ao mesmo tempo, ser ativamente protegido da ficção segundo a qual "os seres humanos de boa vontade decidem em nome do interesse geral”, e ativado pela obrigação de colocar o problema associado ao vírus ou ao rio "em presença” daquele que, do contrário, correria o risco de ser desqualificado como "interesse egoísta”, nada tendo a propor e criando um obstáculo à "conta comum” em formação?

$\mathrm{O}$ que irei descrever a esse respeito, e que prolonga as teses desenvolvidas no sétimo volume de Cosmopolitiques, Pour en finir avec la tolérance, é uma abordagem parcial. Ela prolonga a associação proposta entre "emergência" e "arte do químico" de um modo um pouco diferente dos casos já citados (discurso [palabre], ritual 
de bruxas), pois a maneira como eu considerei esses casos visava, antes de mais nada, a fazer sentir a "arte” lá onde estaríamos tentados a falar de "crença” ou de superstição. A ênfase foi colocada na dimensão da "ativação”, naquilo que confere a um problema o poder de obrigar a pensar. A questão da ativação é experimental e tem necessidade de um aprendizado efetivo de receitas, de maneiras de proceder que nenhuma proposição tem o poder de antecipar ${ }^{\text {II }}$. Mas a arte do químico possui um outro aspecto que pode nos guiar: é uma arte da heterogeneidade, da colocação em presença de corpos enquanto heterógenos. Esse aspecto é levado em conta no discurso [palabre] (interdição de retornar às intenções de quem fala, isto é, ao "em comum" que permite que um pretenda compreender o outro) e ele foi objeto de muitas atenções em todos os grupos nos quais, como no caso das "bruxas", o empowerment está em jogo. Papéis foram criados, cujos constrangimentos criam as salvaguardas que protegem a emergência dos tipos de entendido e mal-entendido "espontâneos" que dominam nossas reuniões de "boa vontade”. É essa noção de papéis heterogêneos que eu vou prolongar.

$\mathrm{O}$ artifício que constitui o papel a ser sustentado faz existir o heterogêneo contra a tão poderosa tentação de tomadas de posição em nome do que autoriza a conta comum (interesse geral, racionalidade, progresso etc.). Um tal papel não é uma mentira, exceto quando nos lembramos que todo mentiroso é transformado pela sua mentira. Há uma eficácia própria ao papel, que os comediantes conhecem bem: o papel não é apenas sustentado, ele "sustenta” aquele que o endossa.

Como distribuir os papéis? É preciso evitar pensar aqui em termos de papéis estereotipados, pois, nos termos da ecologia política, é em torno de cada problema que eles devem se determinar. Em Pour en finir avec la tolérance, eu propus, primeiramente, distinguir entre a figura do expert e a do diplomata.

O expert é aquele cuja prática não é ameaçada pelo problema discutido, e seu papel exigirá dele que se apresente, e apresente aquilo que sabe, de um modo que não prejulgue a maneira como esse conhecimento será levado em conta. Um tal constrangimento faz provação, pois ele se opõe ativamente ao conjunto das retóricas que ligam um conhecimento às pretensões que costumam curto-circuitar o político com temas tais como definição objetiva do problema, abordagem racional, progresso etc. É o conhecimento no sentido de que ele se propõe como pertinente, suscetível de se articular a outros conhecimentos, de ter necessidade de outros conhecimentos para encontrar uma significação em relação ao problema posto, que é acolhido; e toda pretensão de lhe atribuir uma autoridade, de apresentá-lo como aquilo cuja decisão deveria poder ser deduzida, será "notada”: o expert "saindo do seu papel”

II Não é impossível que a categoria do que chamamos de o "público" possa desempenhar aqui um papel importante, algo análogo àquele do coro nas tragédias gregas. O coro fazia eco à situação trágica, interrogava-se, temia, pensava "com" o desdobramento implacável de suas peripécias, e isso de uma maneira às vezes aparentemente "rasa” para os amantes de tragédia insuperável, uma maneira que fazia existir ativamente a Cidade como aquilo que se deve proteger contra esse gênero de tragédia. Poderíamos adiantar que os "júris de cidadãos" desempenham um papel desse tipo: recusando-se a se engajar nas batalhas de saber, sua presença impõe aos beligerantes não se definirem uns contra os outros, mas em face de questões que não pertencem a nenhum deles. 
suscitará dúvidas quanto à confiabilidade da sua contribuição. O papel constitui, portanto, uma verdadeira provação, e é inútil dizer que essa provação implica uma modificação bastante drástica da atividade profissional de pesquisador: o tipo de segurança conferido por um paradigma, no sentido de Kuhn, se torna aqui uma deficiência, pois o expert "sob paradigma" verá toda situação como atribuindo um lugar central ao seu paradigma.

A aposta eto-ecológica é a de que o expert possa aceitar esse constrangimento, pois, seja qual for a forma como a decisão integrará o seu saber, isso não é colocado em questão. Em contrapartida, o diplomata está lá para dar voz àqueles cuja prática, o modo de existência, o que comumente chamamos de identidade, estão ameaçados por uma decisão. "Se vocês decidirem isso, vocês nos destruirão", um tal anúncio é corrente e pode advir de toda parte, inclusive dos grupos que, em outros casos, delegam experts. Mas muitas vezes ouvimos: "reflexo identitário" ou "expressão de interesses corporativos (portanto, egoístas)", e respondemos: é o preço do progresso ou do interesse geral. A diplomacia intervém usualmente entre a guerra provável e a paz possível, e tem o grande interesse de definir os potenciais beligerantes segundo o modo da igualdade. O papel dos diplomatas é, portanto, antes de mais nada, o de suspender a anestesia produzida pela referência ao progresso ou ao interesse geral, o de dar voz àqueles que se definem como ameaçados, de um modo a fazer hesitar os experts, a obrigá-los a pensar na possibilidade de que as suas decisões sejam um ato de guerra.

A paz se faz a dois. Para que a diplomacia seja possível, é preciso que aqueles que representam os diplomatas admitam a possibilidade de alguma paz e se definam, portanto, como capazes de participar de sua invenção. Essa condição é pesada, pois ela implica uma capacidade de "consulta" quando do "retorno dos diplomatas", a capacidade de vislumbrar, face ao que eles propõem, a diferença entre o que pode ser aceito - o que poderá impor alguma modificação a certos hábitos, mas que não destruirá aquilo que "faz sustentar", que "prende" ou "obriga" - e o que não pode ser aceito - traição dos diplomatas. Assim, no caso da experimentação animal que mencionei mais acima, a proposição diplomática é de que os pesquisadores deveriam poder suportar, sem se proteger, as consequências da experimentação que eles vislumbram; que eles não definam os rituais que os protegem como aquilo que não lhes pode ser retirado sob pena de destruí-los.

Eu escolhi o termo "consulta" pois ele pode ser conveniente tanto no domínio político como ali onde existem invisíveis que não partilham as razões humanas, que são insensíveis aos "compromissos", mas que cabe consultá-los pois a sua existência significa que os humanos não são os detentores daquilo que faz sua "identidade". Nós estamos de novo lidando com uma aposta "eto-ecológica", que corresponde ao risco de "dar uma chance à paz". Que um povo seja solenemente consultado nos termos que colocam sua identidade em causa, ou que um invisível seja consultado, nos dois casos o oikos próprio à consulta coloca em suspenso os hábitos que nos fazem pensar que sabemos aquilo que sabemos e quem somos, que detemos o sentido daquilo que nos faz existir. A identidade, então, não é um obstáculo, mas uma condição do exercício diplomático, ao menos a identidade "civilizada", que sabe como consultar, como criar o momento da interrogação acerca daquilo que a sustenta (interrogação não reflexiva 
no sentido de que não refletimos "sobre", mas "interrogamos" o que faz sustentar junto, o que obriga, o que importa à prova da modificação proposta).

Que os diplomatas não possam representar senão aqueles que sabem como consultar é o correlato tanto da definição do exercício diplomático como supondo a igualdade das partes quanto da necessidade de diferenciar experts e diplomatas a propósito de cada situação problemática. Não há diferença de natureza entre os que delegam experts e os que enviam diplomatas, mas sim uma diferença em relação à situação. Mesmo os físicos podem precisar de diplomatas se eles sentem que uma decisão os ameaça na sua prática. Mas essa condição é restritiva, pois ela exclui aqueles sobre quem recai a ameaça de uma perturbação em suas vidas sem que nada os tenha preparado para isso, aqueles que acusaremos da célebre recusa "NIMBY" (not in my backyard), pois a única coisa que eles querem saber da situação é que seu "backyard" vai ser colocado em perigo ou destruído. Assim, quando o lobo é reintroduzido, podemos conceber que pastores enviem diplomatas, pois a sua prática, diferentemente de um backyard, possui uma identidade, modos de transmissão, de avaliação - e os hábitos dos pastores, seus modos de definição de si mesmos, dependem de toda uma ecologia complexa, aí compreendidas as subvenções públicas. Mas quando um lugarejo, que nada pediu, se vê ameaçado por um aeroporto próximo, a situação é diferente. É preciso, então, falar não de uma situação hesitante entre a guerra e a paz, mas de uma situação que fará vítimas. A entrada em cena da diplomacia insulta aqueles que não querem se definir como "iguais", pois essa definição mascararia o fato de que eles estão em uma situação de fraqueza e condenados a se "submeter". O perigo é de se reencontrar, como o homem da lei face a Bartleby, em face daqueles a quem gostaríamos, a toda força, de fazer interlocutores, produtores de contraproposições construtivas, enquanto eles prefeririam simplesmente que os deixássemos tranquilos.

As vítimas precisam de "testemunhas" capazes de fazer existir sua presença, aquelas cujo mundo poderia bascular. Talvez esse seja um papel que conviria muito especificamente àqueles que comumente se nomeiam "artistas", pois se trata de fazer passar alguma coisa que não é da ordem de uma posição, de dar sua dignidade e sua importância àquilo que pertence antes à "sensação".

Não mais que a entrada em cena da diplomacia, a presença das vítimas não garante evidentemente o que quer que seja: a proposição cosmopolítica nada tem a ver com o milagre de decisões "que colocam todo o mundo de acordo". O que aqui importa é a proibição do esquecimento, ou pior, da humilhação. Notadamente, aquela que produz a ideia indigna de que uma compensação financeira deveria ser suficiente, essa tentativa obscena de dividir as vítimas, de isolar os relutantes se dirigindo antes àqueles que, por uma razão ou outra, aceitarão se curvar mais facilmente. Tudo terminará talvez com o dinheiro, mas não "pelo" dinheiro, pois o dinheiro não fecha a conta. Aqueles que se reúnem devem saber que nada poderá apagar a dívida que liga sua eventual decisão às suas vítimas.

Eu apresentei, no início deste texto, o "cosmos" como um operador de igualdade por oposição a toda noção de equivalência. Os papéis que acabo de caracterizar sumariamente correspondem a essa ideia. Nenhuma situação problemática se dirige a protagonistas definidos como intercambiáveis, de forma que entre eles 
uma medida comum permitiria colocar na balança os interesses e argumentos. A igualdade não significa que todos possuem "igualmente o mesmo direito de voz", mas que todos devem estar presentes de um modo que confira à decisão o seu grau máximo de dificuldade, que proíba qualquer atalho, qualquer simplificação, qualquer diferenciação a priori entre aquilo que conta e aquilo que não conta. O cosmos, tal como ele figura na proposição cosmopolítica, não possui representante, ninguém fala em seu nome e ele não pode ser feito objeto de nenhum procedimento de consulta. O seu modo de existência se traduz pelo conjunto dos modos de fazer, dos artifícios cuja eficácia é a de expor aqueles que terão que decidir, de constrangê-los a esse pavor que eu associei ao grito de Cromwell. Em resumo, trata-se de abrir a possibilidade de que ao murmúrio do idiota se responda não, por certo, com a definição "daquilo que há de mais importante”, mas com a desaceleração sem a qual não pode haver criação.

Eu ressaltei que a proposição cosmopolítica não é uma proposição vale-tudo, aquela que "nós" poderíamos apresentar a todos como igualmente aceitável por todos. Ela é muito mais uma maneira de civilizar, de tornar "apresentável" essa política que temos, um pouco exageradamente, a tendência de pensar como um ideal neutro, bom para todos. Evidentemente, nunca é demais ressaltar, essa proposição nada tem a ver com um programa, mas não é inútil enfatizar que tudo aquilo que, de forma muito evidente, lhe faz obstáculo, associando-a à uma utopia, é igualmente o que dificulta colocação em política, no sentido clássico, de nossos problemas. E aí está, talvez, a sua eficácia aqui e agora. Ela não inova em nada o diagnóstico dos obstáculos, daquilo que condena a nossa política a ser nada mais do que uma arte (mais próxima, antes, da magia negra), de conduzir os rebanhos humanos, mas ela pede àqueles que lutam que não entreguem a essa luta o poder de definir uma unidade advinda enfim do gênero humano. $\mathrm{O}$ chamado à unidade ontem endereçado aos trabalhadores de todos os países, ou hoje aos cidadãos de um novo regime cosmopolita de tipo kantiano ${ }^{\mathrm{I2}}$, comunica de maneira precipitada o grito "um outro mundo é possível!" com a definição da legitimidade daqueles serão os autores confiáveis desse outro mundo.

Nós não somos confiáveis! E sobretudo quando pretendemos participar da necessária criação de um "senso comum cosmopolítico, um espírito de reconhecimento da alteridade do outro capaz de apreender as tradições étnicas, nacionais e religiosas e de fazer com que elas se beneficiem de suas trocas mútuas"ז3. E sobretudo quando a necessidade dessa criação de um "bom mundo comum", onde cada um estaria apto e pronto para ver "com os olhos do outro" 4 , se funda naquilo que deve ser aceito por todos: não mais em um interesse geral sempre discutível, mas em um argumento de peso que constitui a urgência por excelência, a sobrevida da própria humanidade.

Ulrich Beck o pressentiu. A passagem de um certo temor reverbera no fim de seu livro. E podemos compreendê-lo. Esse moralismo da reciprocidade que gostamos tanto de pensar não estaria fadado a denunciar os "maus", aqueles para quem, por exemplo, ver com os olhos do outro é roubar-lhe a alma? A falsa simplicidade de uma boa vontade sedenta de trocas mútuas não acabaria sempre por denunciar e

I2 Ver: BECK, U. Pouvoiret contre-pouvoirà l'ère dela mondialisation. Paris: Flammarion- Aubier, 2003.

I3 Ibidem, p. I3.

I4 Ibidem, p. I2. 
comprometer-se a pacificar aquilo que lhe faz obstáculo? No entanto, já é tarde, o interstício novamente se fecha e o projeto permanece intacto, distinguindo-se do pesadelo que seria o "cosmopolitismo realmente existente, governado e tiranizado pelas suas consequências secundárias, não intencionais e não percebidas”.5. $O$ autor lava as mãos: o projeto que ele apresentou como dotado de razões válidas para todos não será reescrito, livre, ao que parece, de consequências secundárias, entretanto desde já perceptíveis.

Pensar a partir dessas consequências ditas secundárias, temerosas face à ideia de que um senso comum qualquer possa aplainar, pacificar a questão sempre delicada, hesitante entre a guerra e a paz, que é todo encontro entre heterogêneos, não é certamente responder à urgência. É mesmo idiota, não apenas do ponto de vista das mobilizações proclamadas em nome da urgência, mas também em face da urgência ela mesma, inegável. É preciso ousar dizer que o murmúrio do idiota cósmico é indiferente ao argumento da urgência como a qualquer outro. Ele não o nega, ele apenas coloca em suspenso os "e portanto..." dos quais nós, tão plenos de boa vontade, tão empreendedores, sempre prontos a falar por todos, somos os mestres.

\section{SOBRE A AUTORA}

ISABELLE STENGERS é professora de Filosofia das Ciências da Universidade Livre de Bruxelas (ULB). 